\title{
Growth Performances and Carcass Characteristics of Broiler Chickens Fed Akasya [Samanea Saman (Jacq.) Merr.] Pod Meal
}

\author{
F. C. C. Reyes $^{\mathrm{a}}$, A. T. A. Aguirre ${ }^{\mathrm{a}}$, E. M. Agbisit Jra , F. E. Merca ${ }^{\mathrm{b}}$, G. L. Manulat ${ }^{\mathrm{c}}$, \& A. A. Angeles ${ }^{\mathrm{c}, *}$ \\ ${ }^{a}$ Institute of Animal Science, College of Agriculture and Food Science, University of the Philippines Los Baños, \\ College, Laguna \\ 'Institute of Chemistry, College of Arts and Sciences, University of the Philippines Los Baños, College, Laguna \\ 'Dairy Training and Research Institute, College of Agriculture and Food Science, University of the Philippines Los \\ Baños, College, Laguna \\ *Email of corresponding author: aaangeles8@up.edu.ph \\ (Received 20-11-2017; Reviewed 16-12-2017; Accepted 31-01-2018)
}

\begin{abstract}
Akasya pods are seasonally abundant and are good sources of protein and energy and have been considered as an alternative feed source for livestock. This study was conducted to determine the effects of feeding Akasya pod meal (APM) on the growth performances and carcass characteristics of broiler chickens. Three hundred straight-run 7-day-old Cobb broiler chicks were randomly allocated to five dietary treatments containing $0 \%, 0.5 \%, 1.0 \%, 2.5 \%$, and $5.0 \%$ APM following a completely randomized design. Each treatment was replicated 10 times with 10 birds per replicate. The digestibility of nutrients was also evaluated to determine the effect of different levels of APM on the efficiency of nutrient digestion in broilers. Broilers fed APM level at more than $1.0 \%$ had lower body weights and body weight gains, but feed intake, feed conversion ratio, livability, and carcass characteristics were not affected by increasing levels of APM. The digestibility of crude protein (CP), crude fiber (CF), nitrogen free extract (NFE), ether extract (EE), and energy were the same in broilers across treatments. Increased income over chick and feed cost (IOFCC) was generated from broilers fed diets with $0.5 \%$ APM, but progressively declined as APM level in the diet was increased. In conclusion, APM can be used in broiler diets at inclusion levels up to $1.0 \%$ wherein growth performance and carcass characteristics were optimum in broilers and income generated was improved at $0.5 \%$ level.
\end{abstract}

Keywords: Akasya pod, broilers, nutrient digestibility, performance, unconventional feed source

\section{INTRODUCTION}

In poultry production, about $70 \%$ of the total cost can be attributed to feed cost (Banson et al. 2015). Any attempt to improve commercial poultry production and increase its efficiency needs to focus on the use of locally available new ingredients (Kamalzadeh et al., 2008) that can reduce the competition that exists between human and poultry for conventional ingredients and reduce feed cost (Girma et al. 2011). Alternative feed ingredients open an opportunity to lower feed cost. However, indigenous feed ingredients in developing countries are often underutilized, wasted, or inefficiently used due to poor characterization of chemical components. Akasya tree [Samanea saman (Jacq.) Merr.] is widespread in the Philippines. A mature Akasya tree can yield $500-600 \mathrm{~kg}$ pods annually which are commonly fed to ruminants (Rath et al., 2014). It has been observed that Akasya pods are used as feed supplement in concentrates for both livestock and poultry (Flores, 2002).

Wide ranges of values were reported from various countries on the nutrient composition of akasya pods. On DM basis, an akasya pod contains $12.83 \%-31.32 \%$ crude protein (CP), $1.30 \%-17.56 \%$ ether extract (EE), $11.78 \%-28.14 \%$ crude fiber (CF), $44.38 \%-81.79 \%$ nitrogen free extract (NFE), and total phosphorus ( $\mathrm{P}$, total) of $0.18 \%-0.90 \%$ (Anantasook \& Wanapat, 2011). Acacia species, however, contains high polyphenolic compounds and fiber (Mokoboki et al., 2013). In addition, akasya pods contains tannins which can make complex compounds with proteins, sugars, nucleic acids, and minerals (Ukoha et al., 2011; Saxena et al., 2013) that may reduce the bioavailability of nutrients leading to poor performance. According to Flores (2002) and Staples \& Elevitch (2006), akasya pods contain $4.0 \%$ of condensed tannin, while Angeles et al. (2013) observed that the pods contain $16.42 \%$ tannins.

Titration feeding study is important to determine the optimum level of APM without deteriorating the performance of animals. Inclusion rates of akasya pods have been evaluated in boilers by Hagan et al. (2016) as replacement for soybean meal and fishmeal and recommended that inclusion of akasya pods should be 20 g per $100 \mathrm{~kg}$ of broiler diets for improved growth rate and higher profit margin. Moreover, studies by Barcelo et al. (2013) and Hagan et al. (2016) in broilers starting 
on days 21 and 28, respectively, showed no effects on broiler performance even though the experimental diets were not formulated to be isocaloric and isonitrogenous. The aim of this study is to determine the effect of feeding different levels of APM formulated to be isocaloric and isonitrogenous, on growth performances, carcass characteristics, nutrient digestibility, and diet economics of broilers from starter to finisher stages.

\section{MATERIALS AND METHODS}

\section{Feeding Trial}

Three hundred 7-day-old group-brooded broiler chicks were randomly allocated to five dietary treatments with $0 \%, 0.5 \%, 1.5 \%, 2.5 \%$, and $5.0 \%$ Akasya pod meal (APM). Each treatment was replicated 10 times with 10 birds per replicate. Fallen whole, ripe, and clean Akasya pods were oven-dried at $105^{\circ} \mathrm{C}$ for $24 \mathrm{~h}$ and were ground to pass through a \#20 Tyler mesh. Chemical analysis of Akasya pods is presented in Table 1. Ingredient composition and calculated nutrient analysis of starter and finisher diets containing different levels
APM are presented in Tables 2 and 3, respectively. The experimental diets were formulated to meet or exceed the minimum nutrient requirements set by PHILSAN (2010).

The experimental broilers were housed in battery cages with stocking density of 1.0 bird sq. $\mathrm{ft}^{-1}$. Starter diets were given from days 8-28 while finisher diets

Table 1. Chemical analysis of Akasya pods

\begin{tabular}{lc}
\hline Nutrient $^{1}$ & Percent in APM \\
\hline Dry matter & 88.70 \\
Crude protein & 15.37 \\
Neutral detergent fiber & 42.86 \\
Ether extract & 1.95 \\
Cellulose & 9.77 \\
Hemicellulose & 10.53 \\
Phosphorous & 0.76 \\
Tannin & 16.42 \\
\hline
\end{tabular}

${ }^{1}$ All nutrients are expressed in $\%$ dry matter basis except for the dry matter which is in \% fresh basis

Table 2. Ingredients and nutrient content (as fed basis) of starter diets containing different levels of Akasya pod meal (APM)

\begin{tabular}{|c|c|c|c|c|c|}
\hline \multirow{2}{*}{ Ingredients } & \multicolumn{5}{|c|}{ APM level, \% } \\
\hline & 0 & 0.5 & 1 & 2.5 & 5 \\
\hline Yellow corn & 53.96 & 53.72 & 53.47 & 53.09 & 52.85 \\
\hline Soybean oil meal & 33.11 & 33.11 & 33.11 & 32.95 & 32.46 \\
\hline Akasya pod meal & 0 & 0.5 & 1 & 2.5 & 5 \\
\hline Rice bran & 7.5 & 7.5 & 7.5 & 6.39 & 3.3 \\
\hline Crude coconut oil & 1.31 & 1.33 & 1.36 & 1.5 & 1.79 \\
\hline Copra meal & 0.56 & 0.28 & 0 & 0.01 & 1.01 \\
\hline Limestone & 1.47 & 1.47 & 1.47 & 1.47 & 1.47 \\
\hline Monodicalcium phosphate & 1.18 & 1.18 & 1.18 & 1.18 & 1.21 \\
\hline Iodized salt & 0.35 & 0.35 & 0.35 & 0.35 & 0.35 \\
\hline DL-methionine & 0.06 & 0.06 & 0.06 & 0.06 & 0.06 \\
\hline Choline chloride $50 \%$ & 0.15 & 0.15 & 0.15 & 0.15 & 0.15 \\
\hline Vitamin premix ${ }^{*}$ & 0.12 & 0.12 & 0.12 & 0.12 & 0.12 \\
\hline Mineral premix ${ }^{* *}$ & 0.13 & 0.13 & 0.13 & 0.13 & 0.13 \\
\hline Mold inhibitor & 0.05 & 0.05 & 0.05 & 0.05 & 0.05 \\
\hline Anti-coccidia & 0.05 & 0.05 & 0.05 & 0.05 & 0.05 \\
\hline Total & 100 & 100 & 100 & 100 & 100 \\
\hline \multicolumn{6}{|l|}{ Calculated Nutrient Content: } \\
\hline Metabolizable energy, kcal/kg & 2900 & 2900 & 2900 & 2900 & 2900 \\
\hline Crude protein, $\%$ & 20.7 & 20.7 & 20.7 & 20.7 & 20.7 \\
\hline Ether extract, \% & 4.7 & 4.7 & 4.7 & 4.7 & 4.7 \\
\hline Crude fiber, \% & 3.47 & 3.5 & 3.53 & $3 . .64$ & 3.86 \\
\hline Calcium, \% & 0.87 & 0.87 & 0.87 & 0.87 & 0.87 \\
\hline Total phosphorus, \% & 0.81 & 0.81 & 0.81 & 0.8 & 0.78 \\
\hline Avail. phosphorus, \% & 0.44 & 0.44 & 0.44 & 0.44 & 0.44 \\
\hline Lysine, \% & 1.1 & 1.1 & 1.1 & 1.1 & 1.1 \\
\hline Met + Cys, \% & 0.72 & 0.72 & 0.72 & 0.72 & 0.72 \\
\hline Tannin, $\%$ & 0 & 0.08 & 0.16 & 0.41 & 0.82 \\
\hline
\end{tabular}

*Per kg vitamin premix contains: Vitamin A (10,000,000 IU), Vitamin D3 (2,000,000 IU), Vitamin E (20,000 IU), Vitamin K3 (750mg), Vitamin B1 (500mg), Vitamin B2 (3,500mg), Vitamin B6 (3,000mg) Vitamin B12 (12mg), Niacin (25,000mg), Pantothenic Acid (10,000mg), Folic Acid (500mg), Biotin (50mg), Antioxidant $(25,000 \mathrm{mg})$, Carrier $(+\mathrm{mg})$

**Per kg mineral premix contains: Iron (115,000mg), Manganese (50,000mg), Iodine (850mg), Selenium (150mg), Zinc (50,000mg), Copper (10,000mg), Carrier $(+\mathrm{mg})$. 
Table 3. Ingredients and nutrient content (as fed basis) of finisher diets containing different levels of Akasya pod meal (APM)

\begin{tabular}{|c|c|c|c|c|c|}
\hline \multirow{2}{*}{ Ingredients } & \multicolumn{5}{|c|}{ APM level, $\%$} \\
\hline & 0 & 0.5 & 1 & 2.5 & 5 \\
\hline Yellow corn & 53.48 & 53.34 & 53.92 & 54.07 & 55.9 \\
\hline Soybean oil meal & 31.4 & 31.29 & 31 & 30.75 & 29.7 \\
\hline Akasya pod meal & 0 & 0.5 & 1 & 2.5 & 5 \\
\hline Rice bran & 10 & 9.77 & 8.95 & 7.2 & 3.41 \\
\hline Crude coconut oil & 1.37 & 1.4 & 1.37 & 1.7 & 2.14 \\
\hline Limestone & 1.07 & 1.07 & 1.07 & 1.07 & 1.07 \\
\hline Monodicalcium phosphate & 1.88 & 1.83 & 1.89 & 1.91 & 1.98 \\
\hline Iodized salt & 0.3 & 0.3 & 0.3 & 0.3 & 0.3 \\
\hline Choline chloride $50 \%$ & 0.15 & 0.15 & 0.15 & 0.15 & 0.15 \\
\hline Vitamin premix ${ }^{*}$ & 0.12 & 0.12 & 0.12 & 0.12 & 0.12 \\
\hline Mineral premix ${ }^{* *}$ & 0.13 & 0.13 & 0.13 & 0.13 & 0.13 \\
\hline Mold inhibitor & 0.05 & 0.05 & 0.05 & 0.05 & 0.05 \\
\hline Anti-coccidia & 0.05 & 0.05 & 0.05 & 0.05 & 0.05 \\
\hline Total & 100 & 100 & 100 & 100 & 100 \\
\hline \multicolumn{6}{|l|}{ Calculated Nutrient Content: } \\
\hline Metabolizable energy, kcal/kg & 2900 & 2900 & 2900 & 2900 & 2900 \\
\hline Crude protein, $\%$ & 20 & 20 & 20 & 20 & 20 \\
\hline Ether extract, \% & 5 & 5 & 5 & 5 & 5 \\
\hline Crude fiber, \% & 3.51 & 3.55 & 3.55 & 3.6 & 3.6 \\
\hline Calcium, \% & 0.82 & 0.82 & 0.82 & 0.82 & 0.82 \\
\hline Total phosphorus, \% & 0.97 & 0.96 & 0.96 & 0.96 & 0.91 \\
\hline Avail. phosphorus, $\%$ & 0.59 & 0.59 & 0.59 & 0.59 & 0.59 \\
\hline Lysine, \% & 0.93 & 0.93 & 0.93 & 0.93 & 0.93 \\
\hline Meth + Cys, \% & 0.64 & 0.64 & 0.64 & 0.64 & 0.64 \\
\hline Tannin, $\%$ & 0 & 0.08 & 0.16 & 0.41 & 0.82 \\
\hline
\end{tabular}

*Per kg vitamin premix contains: Vitamin A (10,000,000 IU), Vitamin D3 (2,000,000 IU), Vitamin E (20,000 IU), Vitamin K3 (750mg), Vitamin B1 (500mg), Vitamin B2 (3,500mg), Vitamin B6 (3,000mg) Vitamin B12 (12mg), Niacin (25,000mg), Pantothenic Acid (10,000mg), Folic Acid (500mg), Biotin (50mg), Antioxidant $(25,000 \mathrm{mg})$, Carrier $(+\mathrm{mg})$

**Per kg mineral premix contains: Iron (115,000mg), Manganese (50,000mg), Iodine (850mg), Selenium (150mg), Zinc (50,000mg), Copper (10,000mg), Carrier $(+\mathrm{mg})$

were provided from days 29-42. Feed and water were provided at all times. Vaccination against New Castle Disease was done on days 7 and 21. Feed intake and mortality were recorded daily. Broilers were weighed on days 7,28 , and 42 . After slaughtering, the dressing percentage was determined.

\section{Carcass Characteristics}

On day 42, one male and one female birds from each replicate were randomly sampled, dressed, and chilled overnight. Dressing percentage, cut up yield, and sizes of cuts were determined. The lean, fat, and bone compositions of the whole leg and breast retail cuts were also recorded. Breast samples were wrapped in aluminum foil and steamed until the internal temperature reached $160^{\circ} \mathrm{C}$.

\section{Digestibility Trial}

On day 35, three birds from each treatment were randomly selected and transferred to individual cages. The first three days of the metabolism trial served as the adjustment period. On day 38, collection of excreta was done for three consecutive days. The amount of feed offered and refused was recorded during the collection period. Plastic trays were installed under each cage to facilitate total collection of excreta. Feathers and scales were removed from the collected excreta. The samples of excreta were oven-dried at $70^{\circ} \mathrm{C}$ until constant weight. The dried excreta samples from each bird collected for three days were pooled, weighed, and ground to pass $0.5 \mathrm{~mm}$ screen and were subjected for proximate analysis and gross energy determination.

The percentages of digestible nutrient values were determined following the formula of Roxas, (2006) wherein;

Coefficient of digestibility $(\%)=$

[(Nutrient intake in feeds - Nutrient in excreta) / Nutrient intake in feeds] $\times 100$

$\%$ Digestible nutrient $=$

(Coefficient of digestibility $\times$ Nutrient of feeds) / 100

Feed and excreta samples were analyzed for subjecting proximate fiber fractions, energy as well as phosphorus and calcium contents following the procedures AOAC (2005) and Van Soest \& Robertson (1985). 


\section{Statistical Analysis}

All data for growth parameters, carcass characteristics, and nutrient digestibility were subjected to analysis of variance (ANOVA) in a completely randomized design (CRD) using SAS (SAS Institute, 2012). Comparison of treatment means was done using Tukey's HSD test. Statistical significances and tendencies were set at $P \leq$ 0.05 .

\section{Economic Analysis}

The cost of feeds, acquisition and preparation of APM and return from sales of finished broilers were computed to determine the income over feed and chick cost (IOFCC) which was calculated using the following formula (Magpantay et al., 2013):

Income over feed and chick cost $=$

[(Average wgts of broilers, $\mathrm{kg}$ ) $\times$ (Price per $\mathrm{kg}$ live weight of broiler $)]-[$ (Price of day-old chicks $)+($ Total feed consumed $) \times($ Price of feed $)]$

\section{RESULTS}

The level of crude fiber in the diet increased as the level of Akasya pod meal (APM) was increased (Table 4). Body weight and body weight gains after 42 days were greater in broilers fed $0 \%, 0.5 \%$, and $1 \%$ APM wherein broilers fed $0 \%$ had the greatest body weight and weight gain (Table 5). Broilers fed $2.5 \%$ and 5.0\% APM had lower body weights and weight gains. Broilers fed 5.0\% APM had the lowest body weight and weight gain after 42 days. Moreover, feed consumption, feed conversion ratio, and percent livability of broilers were not affected by feeding different levels of APM $(\mathrm{P}>0.05)$. In addition, dressing percentage with and without giblets, sizes of cuts, lean, fat, bone composition of the whole leg and breast retail cuts of broilers did not differ $(\mathrm{P}>0.05)$ among treatments (Table 6).

Broilers fed diets with $0 \%, 0.5 \%$, and $1.0 \%$ APM were observed to have greater digestible $\mathrm{CP}$ coefficients while broilers fed diets with $2.5 \%$ and 5.0\% APM had lesser digestible coefficients in both $\mathrm{CP}$ and crude fat (EE). Inclusion of APM beyond $1.0 \%$ in the diet significantly reduced $(\mathrm{P}<0.05)$ the digestibility of $\mathrm{CP}$ and $\mathrm{EE}$. However, there was no difference $(P>0.05)$ on the digestible nutrients in increasing levels of APM in broilers diets (Table 7).

Based on the prices of feed ingredients during the conduct of the study, unit cost of feeds decreased as APM inclusion was increased in starter and finisher diets. The income over chick and feed cost generated by broilers fed 0.5\% APM was higher than those fed $0 \%$ APM but progressively declined as APM level in the diet was increased (Table 8).

\section{DISCUSSION}

Broilers fed diets with 2.5 and 5.0\% APM had lower body weights $(\mathrm{BW})$ and $\mathrm{BW}$ gains $(P<0.05)$ at starter and finisher stages. Hagan et al. (2016) observed that broilers fed diets containing $4.0 \%$ and $6.0 \%$ APM had similar BW gains, but had significantly lower BWs than those fed diets containing $0 \%$ and $2.0 \%$ APM and concluded that any slight increase in APM in broiler diets above $2.0 \%$ caused reduction of BW gains in broilers. Reduction of BW gains in broilers can be attributed to the decreased feed intake and the inefficient utilization of dietary nutrients caused by either the presence of anti-nutritional factors or high fiber in the diet (Nwocha et al., 2014 and Walugembe et al., 2014). The fiber content in broiler diets increased with the increasing levels of APM. Loar et al.

Table 4. Proximate and mineral contents of the treatment diets containing different levels of Akasya pod meal (\%)

\begin{tabular}{lccccc}
\hline \multicolumn{1}{c}{ Diets } & \multicolumn{3}{c}{ APM level, \% } & & \\
\cline { 2 - 6 } & 0 & 0.5 & 1 & 2.5 & 5 \\
\hline STARTER & & & & \\
Dry matter & 88.92 & 89.21 & 89.18 & 89.57 & 89.66 \\
Crude protein & 20.90 & 20.43 & 20.28 & 20.97 & 20.65 \\
Ether extract & 4.33 & 4.19 & 4.27 & 4.30 & 4.70 \\
Crude fiber & 2.58 & 2.75 & 3.63 & 4.00 & 4.92 \\
Nitrogen free extract & 54.5 & 54.63 & 54.16 & 53.88 & 52.89 \\
Ash & 6.61 & 7.21 & 6.84 & 6.42 & 6.50 \\
Calcium & 0.99 & 1.02 & 0.99 & 1.00 & 1.01 \\
Phosphorus, total & 0.77 & 0.74 & 0.72 & 0.73 & 0.72 \\
FINISHER & & & & \\
Dry matter & 89.34 & 88.93 & 88.85 & 88.28 & 88.99 \\
Crude protein & 20.11 & 20.16 & 20.00 & 19.95 & 20.07 \\
Ether extract & 5.37 & 5.41 & 5.04 & 4.91 & 5.05 \\
Crude fiber & 2.97 & 3.26 & 4.16 & 4.81 & 5.94 \\
Nitrogen free extract & 55.16 & 53.37 & 52.11 & 52.69 & 51.62 \\
Ash & 5.73 & 6.73 & 7.54 & 5.92 & 6.31 \\
Calcium & 0.96 & 0.96 & 1.02 & 1.02 & 1.02 \\
Phosphorus, total & 0.88 & 0.91 & 1.01 & 0.99 & 0.96 \\
\hline
\end{tabular}


Table 5. Growth performance of broilers fed diets with different levels of Akasya pod meal (APM)

\begin{tabular}{|c|c|c|c|c|c|c|c|}
\hline \multirow{2}{*}{ Variables } & \multicolumn{5}{|c|}{ APM level, $\%$} & \multirow{2}{*}{ SEM } & \multirow{2}{*}{ P-value } \\
\hline & 0 & 0.5 & 1 & 2.5 & 5 & & \\
\hline \multicolumn{8}{|l|}{ Body weight, g } \\
\hline 7 days & 135 & 135 & 135 & 137 & 133 & 0.00 & 0.881 \\
\hline 28 days & 1228 & 1193 & 1267 & 1157 & 1157 & 0.02 & 0.111 \\
\hline 42 days & $2120^{a}$ & $2090^{\mathrm{ab}}$ & $2062^{\mathrm{abc}}$ & $2000^{\mathrm{bc}}$ & $1948^{c}$ & 0.02 & 0.002 \\
\hline \multicolumn{8}{|c|}{ Body weight gain, $\mathrm{g}$} \\
\hline 8-28 days & 1095 & 1057 & 1128 & 1022 & 1020 & 5.00 & 0.123 \\
\hline 29-42 days & 895 & 900 & 800 & 845 & 795 & 8.00 & 0.156 \\
\hline 8-42 days & $1987^{a}$ & $1955^{\mathrm{ab}}$ & $1928^{\mathrm{abc}}$ & $1865^{b c}$ & $1815^{c}$ & 7.00 & 0.002 \\
\hline \multicolumn{8}{|c|}{ Feed consumption, $\mathrm{g}$} \\
\hline 8-28 days & 1878 & 1893 & 1900 & 1862 & 1885 & 2.00 & 0.706 \\
\hline 29-42 days & 2072 & 2040 & 2125 & 2055 & 2118 & 90.00 & 0.983 \\
\hline 8-42 days & 3950 & 3930 & 4025 & 3917 & 4002 & 104.00 & 0.972 \\
\hline \multicolumn{8}{|c|}{ Feed conversion ratio } \\
\hline 8-28 days & 1.73 & 1.80 & 1.69 & 1.83 & 1.85 & 0.022 & 0.305 \\
\hline 29-42 days & 2.35 & 2.28 & 2.68 & 2.43 & 2.66 & 0.120 & 0.189 \\
\hline 8-42 days & 1.99 & 2.01 & 2.09 & 2.10 & 2.21 & 0.025 & 0.165 \\
\hline Livability, \% & 95.00 & 100.00 & 96.67 & 98.33 & 100.00 & 22.67 & 0.307 \\
\hline
\end{tabular}

Note: Means within a row with different superscripts are significantly different $(\mathrm{P}<0.05)$. SEM= Standard error of mean.

Table 6. Carcass characteristics of broilers fed diets with different levels of Akasya pod meal (APM) ns

\begin{tabular}{|c|c|c|c|c|c|c|}
\hline \multirow{2}{*}{ Variables } & \multicolumn{5}{|c|}{ APM level, $\%$} & \multirow{2}{*}{$\mathrm{CV}, \%$} \\
\hline & 0 & 0.5 & 1 & 2.5 & 5 & \\
\hline \multicolumn{7}{|l|}{ Dressing percentage, $\%$} \\
\hline $\mathrm{w} /$ giblets & 78.28 & 78.16 & 78.31 & 78.42 & 80.10 & 2.35 \\
\hline w/o giblets & 75.49 & 73.54 & 73.40 & 73.87 & 75.45 & 3.41 \\
\hline \multicolumn{7}{|l|}{ Retail cut yield, \% } \\
\hline Breast & 44.24 & 40.50 & 42.48 & 41.6 & 41.56 & 8.07 \\
\hline Leg & 34.21 & 34.45 & 34.21 & 34.12 & 33.84 & 5.07 \\
\hline Wing & 13.29 & 14.10 & 13.86 & 14.52 & 13.94 & 5.67 \\
\hline Rib back & 9.62 & 10.95 & 9.55 & 11.42 & 10.67 & 17.96 \\
\hline \multicolumn{7}{|l|}{ Retail cut measurement, cm } \\
\hline Breast length & 14.46 & 14.38 & 14.19 & 14.17 & 13.94 & 3.53 \\
\hline Breast width & 11.23 & 11.08 & 11.19 & 11.38 & 11.26 & 3.81 \\
\hline Thigh length & 7.40 & 7.52 & 7.50 & 7.46 & 7.26 & 2.85 \\
\hline Thigh width & 8.35 & 8.30 & 8.36 & 8.45 & 8.57 & 3.70 \\
\hline Leg length & 11.02 & 11.09 & 10.96 & 10.89 & 11.10 & 1.89 \\
\hline Leg circumference & 15.64 & 15.47 & 15.37 & 15.27 & 15.47 & 2.40 \\
\hline Lean:Fat:Bone & 71:09:20 & 71:09:20 & $71: 10: 20$ & 73:09:18 & 72:09:19 & 8.72 \\
\hline
\end{tabular}

Note: Means within a row with different superscripts are significantly different $(\mathrm{P}<0.05)$. CV= Coefficient of variation.

(2010) observed that broilers fed high concentration of fibrous ingredients had decreased body weight gain and Walugembe et al. (2014) also attributed the lower gains of broiler to high fiber diets.

Feed intake and FCR of broilers in starter and finisher stages were the same across treatments and these findings were the same with the observation of Barcelo et al. (2013). However, Hagan et al. (2016) observed differences in feed intake and FCR of broilers when APM levels were increased. The FCR of broilers in a well-managed system should be in a range of 1.9 to 2.15 depending on the nutrient density and feeding manage- ment of broilers (Kamran et al., 2008). Broilers in both temperate and tropical regions are known to have FCR between 1.8 and 2.5 provided that broilers were fed high energy diets which would result to better FCR (Osti et al. 2017). Feed conversion ratio is the main factor that determines farm profit as feed accounts for more than $70 \%$ of the production costs (Osti et al, 2016). The broilers in this study were able to obtain normal FCR values.

The results on cut-up yield, sizes of cuts, lean, fat, bone composition of the whole leg and breast retail cuts were also in agreement with the observations of Barcelo et al. (2013) who reported that the carcass yield of broil- 
Table 7. Nutrient digestibility in broiler fed with different levels of Akasya pod meal (APM)

\begin{tabular}{lcccccc}
\hline \multicolumn{1}{c}{ Variables } & \multicolumn{5}{c}{ APM level, \% } & \multirow{2}{*}{ P value } \\
\cline { 2 - 6 } & 0 & 0.5 & 1 & 2.5 & 5 \\
Coefficient of digestibility, \% & & & & \\
$\quad$ Crude protein & $76.34 \pm 0.97^{\mathrm{a}}$ & $74.12 \pm 0.85^{\mathrm{a}}$ & $76.14 \pm 4.63^{\mathrm{a}}$ & $69.57 \pm 4.81^{\mathrm{ab}}$ & $64.81 \pm 0.18^{\mathrm{b}}$ & 0.004 \\
$\quad$ Ether extract & $98.43 \pm 1.01^{\mathrm{a}}$ & $90.90 \pm 2.72^{\mathrm{a}}$ & $78.58 \pm 15.93^{\mathrm{ab}}$ & $70.12 \pm 5.60^{\mathrm{a}} \mathrm{b}$ & $61.41 \pm 7.45^{\mathrm{b}}$ & 0.010 \\
$\quad$ Crude fiber & $67.31 \pm 5.19$ & $64.85 \pm 9.60$ & $66.75 \pm 8.36$ & $62.27 \pm 4.95$ & $56.79 \pm 6.05$ & 0.408 \\
$\quad$ Nitrogen-free extract & $49.50 \pm 4.66$ & $54.66 \pm 3.58$ & $52.24 \pm 2.18$ & $55.90 \pm 2.31$ & $56.65 \pm 5.38$ & 0.171 \\
$\quad$ Gross energy & $86.75 \pm 1.17$ & $85.30 \pm 1.43$ & $86.35 \pm 2.00$ & $83.73 \pm 3.89$ & $82.20 \pm 3.13$ & 0.235 \\
Digestible nutrient, \% & & & & & \\
$\quad$ Crude protein & $15.36 \pm 1.23$ & $14.70 \pm 0.20$ & $15.25 \pm 1.57$ & $13.93 \pm 2.17$ & $13.00 \pm 0.69$ & 0.260 \\
$\quad$ Ether extract & $4.26 \pm 0.25$ & $3.81 \pm 0.25$ & $3.36 \pm 0.89$ & $3.04 \pm 0.24$ & $2.92 \pm 0.52$ & 0.148 \\
$\quad$ Crude fiber & $0.52 \pm 0.01$ & $0.49 \pm 0.10$ & $0.48 \pm 0.08$ & $0.46 \pm 0.06$ & $0.41 \pm 0.12$ & 0.454 \\
$\quad$ Nitrogen-free extract & $57.11 \pm 5.51$ & $63.84 \pm 7.10$ & $62.69 \pm 2.62$ & $66.05 \pm 4.51$ & $65.81 \pm 5.62$ & 0.260 \\
Metabolizable energy, $\mathrm{kcal} / \mathrm{kg}$ & $2548 \pm 81.68$ & $2518 \pm 38.84$ & $2530 \pm 67.43$ & $2471 \pm 88.51$ & $2450 \pm 74.51$ & 0.462 \\
\hline
\end{tabular}

Means within a row with different superscripts are significantly different $(\mathrm{P}<0.05)$

Table 8. Economic analysis of broilers fed diets with different levels of Akasya pod meal (APM) using the feed, chick and broilers farm gate prices at the time of the study

\begin{tabular}{|c|c|c|c|c|c|}
\hline \multirow{2}{*}{ Variables } & \multicolumn{5}{|c|}{ APM \% level } \\
\hline & 0 & 0.5 & 1 & 2.5 & 5 \\
\hline Average feed consumed, $\mathrm{kg}$ & 4.22 & 4.2 & 4.29 & 4.18 & 4.27 \\
\hline 0-7 d (booster feed) & 0.27 & 0.27 & 0.27 & 0.27 & 0.27 \\
\hline 8-48 d (starter feed) & 1.88 & 1.89 & 1.9 & 1.86 & 1.88 \\
\hline 29-42 d (finisher feed) & 2.07 & 2.04 & 2.12 & 2.05 & 2.12 \\
\hline Total feed cost, USD ${ }^{1}$ & 1.75 & 1.74 & 1.77 & 1.73 & 1.77 \\
\hline Total feed and chick cost, USD² & 2.1 & 2.09 & 2.12 & 2.08 & 2.12 \\
\hline Average live weight, $\mathrm{kg}$ & 2.12 & 2.09 & 2.06 & 2 & 1.95 \\
\hline Livability, \% & 95 & 100 & 96.67 & 98.33 & 100 \\
\hline Sales from finished broilers, USD 3 & 2.84 & 2.95 & 2.81 & 2.78 & 2.75 \\
\hline Income over feed and chick cost, USD & 0.75 & 0.86 & 0.69 & 0.7 & 0.64 \\
\hline
\end{tabular}

Cost of APM in USD per $\mathrm{kg}$ is at 0.10 .

Direct material cost of feeds in USD per kg for Booster is at 0.608 USD; Starter at 0.402 USD and Finisher at 0.399 USD.

Cost of chick per head in USD at 0.35 .

Cost of $\mathrm{kg}$ live weight of broilers in USD at 1.41.

ers was not affected by the APM inclusion in diets. The results showed that the use of APM in broiler diets did not affect the metabolic fate of nutrients on muscle, fat, or bone tissue deposition in broilers.

Digestible coefficients of $\mathrm{CP}$ and EE were greater in broilers fed diets with APM inclusion less than $2.5 \%$. APM inclusion in broilers diets greater than 2.5\% may result to lower nutrient digestibility specifically $\mathrm{CP}$ and EE which was observed in this study. Increasing fiber levels brought about by increasing APM inclusion in the diet has possible effects on nutrient digestibility. Dietary fiber has been considered as an energy diluent and as an anti-nutritional factor in poultry feeds because of its negative effect on feed intake and nutrient digestibility (Rougière \& Carré, 2010). Under practical feeding conditions, particle size and solubility of the fiber fraction in the digestive environment can affect bird productivity because of their effects on rate of feed passage in the upper part of the GIT and fermentative ability in the distal part (Saki et al., 2011).
The low body weight of broilers fed diets with APM on day 42 contributed to a decline in generated income. Therefore, for cost-effective feeding of broilers using APM, it is recommended that inclusion of APM should be not exceed the $1.0 \%$ inclusion rates for both starter and finisher diets for greater income returns and for better growth performances of broilers.

\section{CONCLUSION}

Akasya pod meal (APM) can be used as a feed ingredient in broiler diets. APM inclusion at not more than $1.0 \%$ is recommended based on the performance of the broilers during study. Income generated was highest at $0.5 \%$ level of APM in the diet. Inclusion levels of $\mathrm{APM}$ in broiler are recommended to be at $0.5 \%$ to $1.0 \%$ in starter and finisher diets for optimum performances of broilers. 


\section{REFERENCES}

Anantasook, N., \& M. Wanapat. 2011. Influence of rain tree pod meal supplementation on rice straw based diets using in vitro gas fermentation technique. Asian-Australas. J. Anim. Sci. 25: 325 - 334. https://doi.org/10.5713/ajas.2011.11131

AOAC, 2005. Official Methods of Analysis of AOAC International. $18^{\text {th }}$ ed. Assoc. Off. Anal.Chem., Arlington.

Angeles, A. A., A. D. Torres \& J. M. B. Raquipo. 2013. Changes in bacterial diversity in the rumen of cattle fed ripe Acacia [Samanea saman (Jacq.) Merr.] pods. Philipp. J. Vet. Anim. Sci. 39:11-20.

Banson, E. K., G. Muthusamy \& E. Kondo. 2015. The import substituted poultry industry; evidence from Ghana. Int. J. Agric. For. 5: 166- 175.

Barcelo, P.M., J. E. Libong \& E. T. Coloma. 2013. Acacia (Samanea saman (JACK) MERR) pods as feeds for broilers. Agriculture, Forestry and Fisheries. 2:235-238. https://doi. org/10.11648/j.aff.20130206.16

Flores, E. M. 2002. Samanea saman (Jacq.) Merr. In J. A. Vozzo (Ed.), Tropical tree seed manual. Agriculture handbook 721. USDA Forest Service, Washington, DC.

Girma, M., M. Urge \& G. Animut. 2011. Ground Prosopis juliflora Pods as Feed Ingredient in Poultry Diet: Effects on Growth and Carcass Characteristics of Broilers. Int. J. Poult. Sci. 10: 970- 976. https://doi.org/10.3923/ijps.2011.970.976

Hagan, M.A.S., D. Armstrong, \& A. Dadson. 2016. Growth performance and economic evaluation of broiler Chicken fed with rain tree (Samanea saman) seed meal. Cogent Food \& Agriculture 2: 1-10. https://doi.org/10.1080/23311932.20 16.1277445

Kamalzadeh, A., M. Rajabbeygi \& A. Kiasat, 2008. Livestock production systems and trends in livestock industry in Iran. J. Agric. Soc. Sci. 4: 183- 188.

Kamran, Z., M. Sarwar, M. Nisa, M.A. Nadeem, S. Mahmood, M.E. Babar \& S. Ahmed. 2008. Effect of low-protein diets having constant energy-to-protein ratio on performance and carcass characteristics of broiler chickens from one to thirty-five days of age. Poult. Sci. J. 87: 468-474. https://doi. org/10.3382/ps.2007-00180

Loar, I.I., R.E. Mortitz, J.S. Donaldson \& J.R.A. Corzo. 2010. Effects of feeding distillers dried grains with solubles to broilers from 0 to 28 days posthatch on broiler performance, feed manufacturing efficiency, and selected intestinal characteristics. Poult. Sci. 89. 2242-2250. https://doi. org/10.3382/ps.2010-00894

Magpantay, V.A., R.K.S. Cu, M.C.R. Oliveros \& U.P.A Hurtada. 2013. Growth performance and carcass drip loss and water holding capacity of broilers fed low density diets supplemented with liquid multi-vitamins and amino acids during periods of stress. Philipp. J. Vet. Anim. Sci. 39:201-210.

Mokoboki, K.H., M. Malatje, W.J. Ng'ambi, \& R.L. Ndlovu. 2013. Short communication: The use of polyethylene glycol in the diagnosis of polyphenolics in the foliage of Acacia species. Asia Life Sciences 24: 103-113.
Nwocha, C.C., O.U. Njoku, \& F.N. Ekwueme. 2014. Phytochemical, antinutrient and amino acid composition of Synsepalum dulcificum pulp. Int. J. Pharm. Biol. Sci. 9: 25-29.

Osti, R., Z. Deyi, S. Virendra, B. Dinesh, \& C. Harshika. 2016. An Economic Analysis of Poultry Egg Production in Nepal. Pakistan Journal of Nutrition. 15: 715-724. https:// doi.org/10.3923/pjn.2016.715.724

Osti, R., D. Bhattarai \& D. Zhou. 2017. Climatic Variation: Effects on Stress Levels, Feed Intake, and Bodyweight of Broilers. Rev. Bras. Cienc. Avic. 19: 489-496. https://doi. org/10.1590/1806-9061-2017-0494

Philippine Society of Animal Nutritionists (PHILSAN). 2010 Feed Reference Standards. $4^{\text {th }}$ ed. 498 . University of the Philippines Los Baños, College, Laguna.

Rath S. C., K. C. Nayak, K. N. Mohanta, C. Pradhan, P. V. Rangacharyulu, S. Sarkar \& S. S. Giri. 2014. Nutritional evaluation of rain tree (Samanea saman) pod and its incorporation in the diet of rohu (Labeo rohita Hamilton) larvae as a non-conventional feed ingredient. Indian J. Fish. 61: $105-111$.

Rougière, N. \& B. Carré. 2010. Comparison of gastrointestinal transit times between chickens from D+ and D- genetic lines selected for divergent digestion efficiency. Animal. 4:1861-1872. https://doi.org/10.1017/S1751731110001266

Roxas, D. B. 2006. Animal Feeds and Feeding: with Emphasis on the Tropics. University of the Philippines Los Baños.

Saki, A. A., H. R. M. Martin, P. Zamani, M. M. Tabatabai \& M. Vatanchian. 2011. Various ratios of pectin to cellulose affect intestinal morphology, DNA quantitation, and performance of broiler chicks. Livest. Sci. 139: 237-244. https:// doi.org/10.1016/j.livsci.2011.01.014

SAS Institute. 2012. SAS User's Guide: Statistics (Version. 9.3 ed.), SAS Inst. Inc., Cary, NC.

Saxena, M., J. Saxena, R. Nema, D. Singh \& A. Gupta. 2013. Phytochemistry of Medicinal Plants. J. Pharmacogn. Phytochem. 1:168-182.

Staples, W. G. \& R.C. Elevitch, R. C. 2006. Samanea saman (rain tree), ver 2.1. In R. C., Elevitch (Ed.), Species profile for Pacific Island agroforestry (pp. 2-7). Permanent Agriculture Resources (PAR), Holualoa, HI.

Ukoha, P. O., E. A. C. Cemaluk, O. L. Naamdi, \& E. P. Madus. 2011. Tannins and other phytochemical of the Samanea saman pods and their antimicrobial activities. African Journal of Pure and Applied Chemistry. 5: 233-244.

Van Soest, P.J. \& J. B. Robertson. 1985. Methods of analysis of dietary neural detergent fiber and non-starch polysaccharides in relation to animal nutrition. J. Dairy Sci. 74: 3585-3597.

Walugembe, M., M.F. Rothschild \& M.E. Persia. 2014. Effects of high fiber ingredients on the performance, metabolizable energy and fiber digestibility of broiler and layer chicks. Anim. Feed Sci. Technol. 188: 46-52. https://doi. org/10.1016/j.anifeedsci.2013.09.012 